\title{
Redescription of Kalliapseudes obtusifrons (Haswell, 1882), from Southeast Australia (Crustacea: Tanaidacea: Apseudomorpha: Kalliapseudidae), with the designation of a lectotype
}

\author{
DAVID T. DRUMM ${ }^{1} \&$ RICHARD W. HEARD ${ }^{2}$
}

Department of Coastal Sciences, University of Southern Mississippi, Gulf Coast Research Laboratory Campus, Ocean Springs, MS 39566-7000.E-mail: 'david.drumm@usm.edu, ${ }^{2}$ richard.heard@usm.edu

\begin{abstract}
Kalliapseudes obtusifrons (Haswell) is redescribed and referred to the genus Kalliapseudes sensu stricto. It can be distinguished from the other members of the genus by the nature of the ventral spines on the propodus of pereopods IV and V, the dorsal setation of the merus and the armature on the dactylus of pereopod VI. A key to the four species of the genus Kalliapseudes known from Australian waters is presented.
\end{abstract}

Key words: Crustacea, Tanaidacea, Apseudomorpha, Kalliapseudes obtusifrons, redescription, Australia

\section{Introduction}

Apseudes obtusifrons Haswell, 1882 was briefly described and illustrated based on a female specimen collected in coastal waters near Port Jackson, New South Wales, Australia (Haswell, 1882). Lang (1949) transferred Haswell's species to the genus Kalliapseudes Stebbing, 1910 and based on carapace similarities considered it as a possible synonym of $K$. macrothrix Stebbing, 1910, which he thought also might be a senior synonym of $K$. primitivus Nierstrasz, 1913. Later when establishing the family Kalliapseudidae, Lang (1956) considered the taxonomic status of $K$. obtusifrons as unsettled. Recently, Guțu (2006) listed K. obtusifrons as a species incertae sedis, but indicated that if Haswell's original description was correct then this species might be a member of the genus Cristapseudes Băcescu, 1980, which is characterized by lacking an exopodite on the cheliped and pereopod I, and by the absence of a sensory organ on the dactylus of pereopods II and III. 
Roger Springthorpe of the Australian Museum was able to locate the type material, a single female syntype, in the collections of the Australian Museum and kindly made it plus another specimen of $K$. obtusifrons available for us to study. A lectotype is designated based on the syntype (Haswell did not designate any types and it is unclear how many specimens he had for the description so according to ICZN Recommendation 73F the specimen is of syntype status). The redescription and proper taxonomic placement of $K$. obtusifrons is the subject of this report. Unless otherwise indicated, the terminology used here follows that of Larsen (2003).

\section{Family Kalliapseudidae Lang, 1956}

\section{Subfamily Kalliapseudinae Lang, 1956}

\section{Kalliapseudes Stebbing, 1910}

Diagnosis (after Guțu, 2006): Antenna with numerous plumose setae on the distal peduncular article. Cheliped and pereopod I with exopodite. Dactylus of pereopods II and III long and slender with one small proximosternal digitiform lobe, ending in a few sensory setae. Pereopods IV and V with some sensory setae on dactylus; unguis absent. Pereopod VI with normal dactylus hooked or claw-shaped.

Remarks. In a recent treatment of genus Kalliapseudes, Guțu (2006) elevated its two existing subgenera, Mesokalliapseudes and Monokalliapseudes, to full generic rank, and erected the monotypic genus Alokalliapseudes to receive Mesokalliapseudes macsweenyi (Drumm, 2003) as its type species. These four genera plus Cristapseudes Băcescu, 1980 presently comprise the subfamily Kalliapseudinae (see Guțu 2006).

\section{Kalliapseudes obtusifrons (Haswell, 1882)}

Figs. 1-4

Apseudes obtusifrons Haswell, 1882: 748-749, Pl. VI, figs. 1-8; 1884: 1003; Richardson, 1912: 584; Nierstrasz, 1913: 10; Lang, 1949: 3.

Kalliapseudes obtusifrons Menzies, 1953: 474, 479, 482; Larwood, 1954: 562; Lang, 1956: 205, 208, 209; Makkaveeva, 1971: 97; Boesch, 1973: 187; Bamber, 1998: 184; 2005: 645; Bamber et al., 2003: 53; Gutu, 2006: 126-127, 138, 141, 153.

Material examined: Female lectotype, total length (TL) $9.5 \mathrm{~mm}$, AM P3322, Port Jackson, New South Wales, 33 ${ }^{\circ} 51^{\prime}$ S, $151^{\circ} 16^{\prime}$ E. - 1 ovigerous female (partially dissected), TL 9 mm, AM P3321, Cabbage Tree Island, New South Wales. Collected before September, 1912.

Diagnosis Mandibular palp with terminal pectinate spiniform seta long and thin (more 
than 7 times as long as wide). Cutting edges of chelae with short spinules increasing in length distally and interspersed with round tubercles. Exopodite of cheliped and pereopod I bearing 2 plumose setae. Ventral spines on propodus of pereopod IV longer on inner surface than on outer surface. Ventral spines on propodus of pereopod V longer on outer surface than on inner surface. Merus of pereopod VI provided with plumose setae on dorsal margin. Dactylus of pereopod VI with 2 distal sensory setae and 2 short spiniform setae on inner half of proximal margin. Uropodal exopodite having 3 articles.

Description (ovigerous female): body (Fig. 1A) 5.8 times as long as broad. Carapace (Fig. 1A) broader than long, 1 pair of mid-lateral setae; rostrum broadly rounded. Pereonites (Fig. 1A) 4 and 5 longest and subequal, 6 and 1 shorter than 2-5, 2 and 3 without anterolateral spiniform projection; setae on anterolateral corners of all pereonites; hyposphaenia absent. Pleon (Fig. 1A). Pleonites subequal; epimera rounded, with several plumose setae and 1 pair of simple setae on dorsal surface; hyposphaenia absent. Pleotelson (Fig. 1A) rounded, posteriorly bifurcate, with several lateral simple setae and with 1 simple seta on either side of tip; slightly shorter than combined length of pleonites 3-5.

Antennule (Fig. 1B). First article about 2.5 times as long as second and third articles combined and about 2.7 times as long as maximum width. Inner flagellum with 4 articles; outer flagellum with 10 articles, and 1 aesthetasc each on articles 4-6, and 2 aesthetascs on article 8. Distal article of both flagella with setae broken off.

Antennae (Fig. 1C). First article with medial extension, bearing 6 plumose setae. Squama with 7 long simple setae. Last peduncle article longer than flagellum, with double row of plumose setae. Flagellum with six articles; distal article with setae broken off. Labrum (Fig. 1D) with apex rounded and with short hairs.

Mandibles (Figs. 1E-G). Right mandible with tridentate incisor process. Left mandible with 9 or 10 denticulations on incisor process; lacinia mobilis with 8 denticulations. Both mandibles with spine row of 5 serrate spines. Mandibular palp uniarticulate with row of long plumose setae and terminating in a sharp pectinate spiniform seta; terminal spiniform seta long and thin, about 7 times as long as wide.

Labium (Fig. 1H). Distal margin provided with hairs and spinulate on outer margin. Palp with long hairs on margins and spinulate on outer proximal margin. Ending in an acuminate inner tip.

Maxillule (Fig. 2A). Inner endite bearing 4 terminally setulate setae and dense row of hairs on outer face. Outer endite with 10 distal spines, 2 subterminal setae and with long hairs on outer face.

Maxilla (Figs. 2B, C). Inner lobe of fixed endite with posterior row of 4 serrate setae and with long row of plumose setae. Outer lobe of fixed endite with multi-toothed spiniform setae on inner half and several serrate and blunt-tipped simple setae on outer half. Inner lobe of moveable endite with 2 serrate and several simple, blunt setae; outer lobe of moveable endite with 3 serrate and 2 plumodenticulate (bearing setules and 
denticles) setae. Outer margin with a few spinous processes.

Maxilliped (Fig. 2D). Basal article fringed with plumose setae along inner margin. Articles 2-4 of palp with double row of long plumose setae on inner margin. Endite (Fig. 2E) with numerous hairs on lateral margins and with plumose setae on distal margin, and with 2 coupling hooks.

Epignath (Fig. 2F).With a setose posterior spine and setose round anterior lobe.

Cheliped (Figs. 2G, H). Basis with several simple setae on ventrodistal corner (only 1 is shown, the rest were broken off). Merus longer than broad, with several simple setae on ventrodistal corner. Carpus more than 2.5 times as long as broad, with double row of long, plumose setae and a distinct line of fusion. Propodus robust, with diagonal row of 15 long, plumose setae and several simple dorsodistal setae; fixed finger about two-thirds the length of dactylus, with several simple setae on outer surface and with simple setae on inner and outer faces near cutting edge increasing in length distally; cutting edge with short spinules increasing in length distally and interspersed with round tubercles; palm with simple setae on outer surface. Dactylus inner and outer surfaces with simple setae distally; cutting edge with long spinules increasing in length distally and interspersed with round tubercles; claw present. Exopodite (Fig. 2I) having 3 articles and distal article bearing 2 long plumose setae.

Pereopod I (Fig. 3A). Basis about 2 times as long as wide, with short simple setae proximally on dorsal margin. Ischium short and naked. Merus longer than broad and shorter than basis, with several simple setae on ventral margin, 1 distal spine on inner surface and 1 dorsodistal spine. Carpus about one-half length of merus, with 2 ventrodistal and 1 dorsodistal spine. Propodus about same length as carpus, with 4 ventral and 2 dorsodistal spines. Dactylus represented by a sensory organ; inner surface with 1 spiniform seta. Exopodite having 3 articles and distal article bearing 2 long plumose setae.

Pereopod II (Fig. 3B). Basis more than 2.5 times as long as broad. Ischium with 3 distal simple setae on ventral margin. Merus shorter than carpus, with one spine on ventral margin. Carpus about 1.5 times as long as broad, with 4 spines on ventral margin and 3 spines on outer surface. Propodus about one-third length of basis, with 7 serrate spines increasing in length distally and with 3 spines on outer surface. Dactylus shorter than basis; digitiform lobe present near base, with 6 sensory setae.

Pereopod III (Fig. 3C). Similar to pereopod II. Carpus with 6 spines on ventral margin.

Pereopod IV (Figs 3D, E). Basis about 2.3 times as long as broad. Merus shorter than carpus, with 1 spine on ventral margin and 2 spines on outer surface. Carpus with 2 spines on ventral margin, 5 spines on inner surface, 6 spines on outer surface and 1 dorsodistal spine. Propodus with spines increasing in length distally, those on inner surface longer than those on outer surface; 5 short, comb-like spines distally on inner surface. Dactylus represented by a sensory organ.

Pereopod V (Figs. 3F, G). Basis broader than pereopod IV, about 2.2 times as long as broad. Merus with 1 spine on ventral margin and 1 spine on outer surface. Carpus with 8 
spines on inner surface, 6 spines on outer surface and 2 distal spines. Propodus with 9 inner surface. Dactylus represented by a sensory organ.

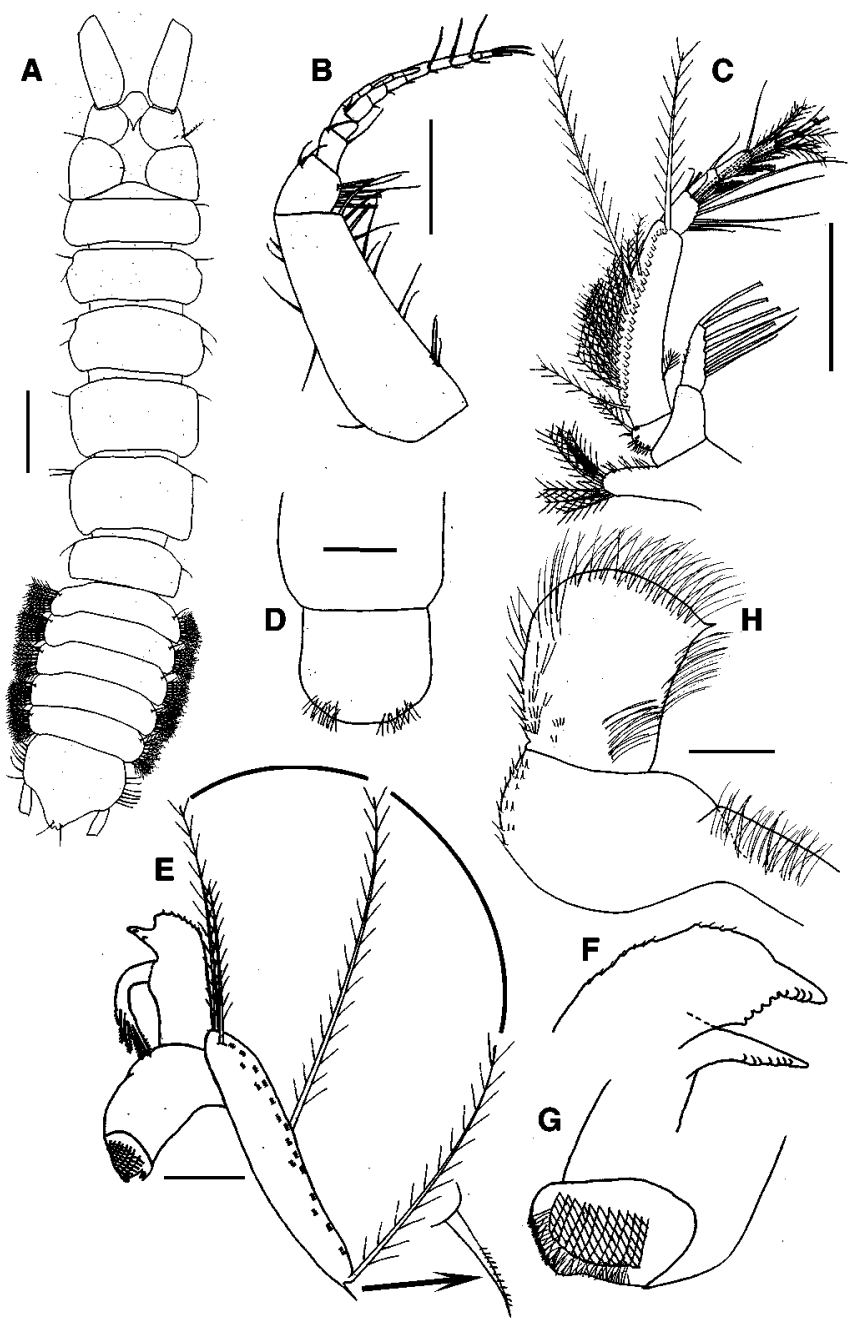

FIGURE 1. Kalliapseudes obtusifrons, ovigerous female. A, dorsal view of body; B, antennule; C, antenna; D, labrum; E, right mandible; $\mathrm{F}$, incisor process and lacinia mobilis of left mandible; $\mathrm{G}$, molar process of left mandible; $\mathrm{H}$, labium. Scale bars: $\mathrm{A}=1.0 \mathrm{~mm}$;, $\mathrm{C}=0.5 \mathrm{~mm} ; \mathrm{D}, \mathrm{E}=0.2 \mathrm{~mm}$; $\mathrm{H}=0.1 \mathrm{~mm}$.

Pereopod VI (Figs. 4A, B). Basis with 6 long, plumose setae on dorsal margin and 4 long, plumose setae on ventral margin. Ischium almost as long as merus. Merus with 3 plumose setae on dorsal margin. Carpus with several simple setae on dorsal and ventral margins. Propodus with 6 long spines and 30 short comb-like spines. Dactylus longer than propodus, with 2 distal sensory setae and 2 short spiniform setae on proximal half; claw 
Pleopods (Fig. 4C). Basal article with 4 plumose setae. Exopodite with 1 article. Both rami with hairs on inner margin.

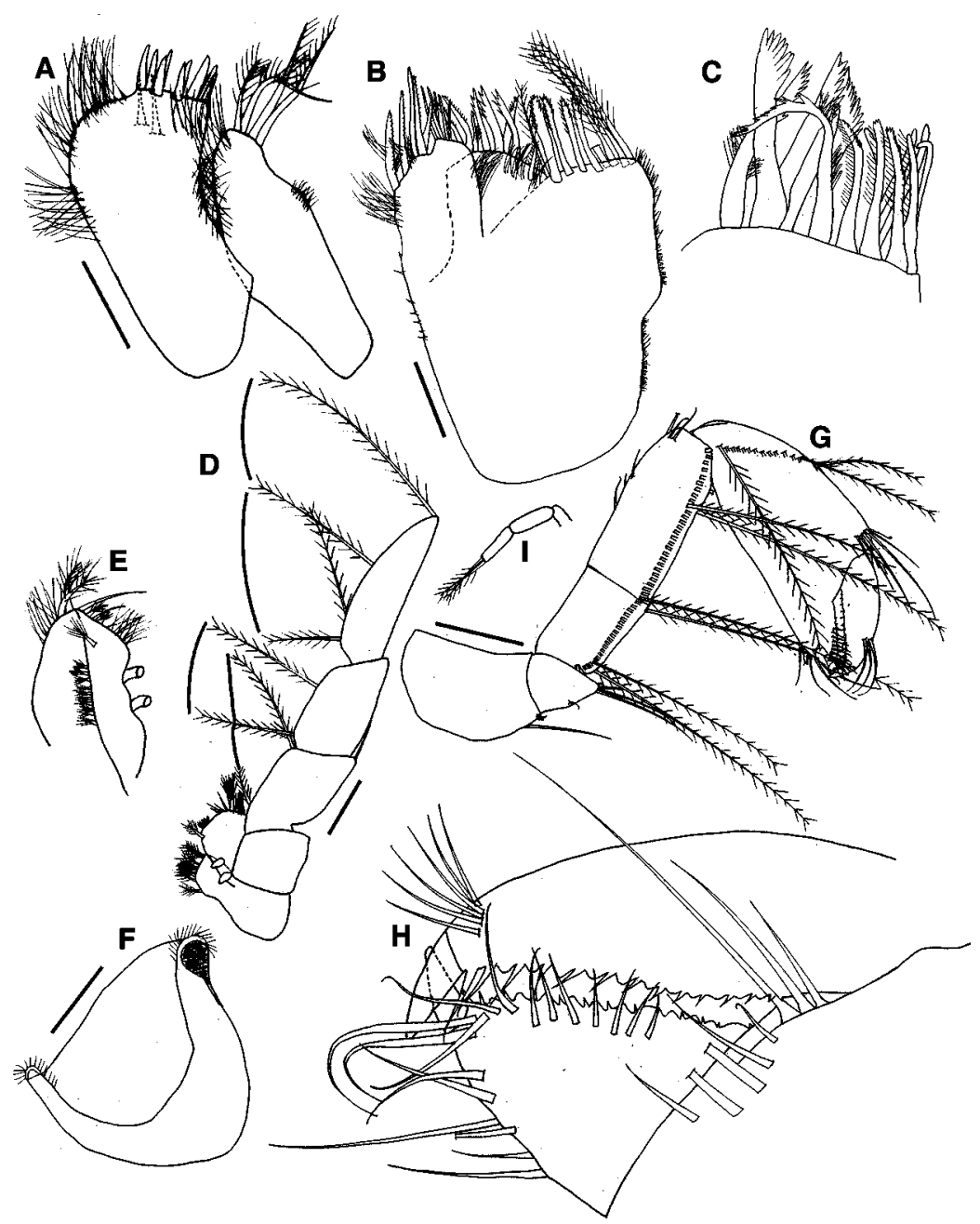

FIGURE 2. Kalliapseudes obtusifrons, ovigerous female. A, maxillule; B, maxilla; C, outer lobe of fixed endite of maxilla; D, maxilliped; E, maxillipedal endite; F, epignath; G, cheliped (inner surface); H, chela (outer surface); I, chelipedal exopodite. Scale bars: A, B $=0.1 \mathrm{~mm}$; D, F = 0.2 $\mathrm{mm} ; \mathrm{G}=0.4 \mathrm{~mm}$.

Uropod (Fig. 4D). Exopodite having 3 articles and distal article bearing 3 long setae. E ndopodite missing (broken off at junction with basal article).

Male. Unknown.

Type locality. Port Jackson, New South Wales, Australia, $33^{\circ} 51^{\prime} \mathrm{S}, 151^{\circ} 16^{\prime} \mathrm{E}$.

Remarks Haswell's (1882) original description and figures for K. obtusifrons, which was originally placed in the genus Apseudes Leach, 1814, lacked the details necessary to 
provide a definitive generic designation. In the original brief description and the few poorly executed illustrations, several important characters, including the presence of exopodites on the cheliped and first pereopod and the sensory organs on the dactylus of the second and third pereopods were not mentioned or figured. Until recently, $K$. obtusifrons was the only known species from Australian waters attributable to the genus Kalliapseudes. In the past two years, however, three additional species, K. struthi Bamber, 2005 from Esperance Bay, Western Australia; K. langi Guțu, 2006 from Moreton Bay, Eastern Australia; and K. multiarticulus Guțu, 2006 from Darwin, Northern Territory, have been described. Based on Guțu's (2006) generic diagnoses, Haswell's "obtusifrons" belongs in the genus Kalliapseudes.



FIGURE 3. Kalliapseudes obtusifrons, ovigerous female. A, pereopod I (inner surface); B, pereopod II (outer surface); C, carpus and propodus of pereopod III, dactylus broken off (inner surface); D, pereopod IV (inner surface); E, carpus, propodus and dactylus of pereopod IV (outer surface); F, pereopod V (inner surface); G, carpus, propodus and dactylus of pereopod V (outer surface). Scale bars: $A=0.4 \mathrm{~mm} ; \mathrm{B}, \mathrm{D}, \mathrm{F}, \mathrm{G}=0.2 \mathrm{~mm} ; \mathrm{C}=0.1 \mathrm{~mm}$. 




FIGURE 4. Kalliapseudes obtusifrons, ovigerous female. A, pereopod VI; B, propodus and dactylus of pereopod VI; C, pleopod; D, uropodal exopodite (endopodite broken off). Scale bars: $0.2 \mathrm{~mm}$.

Kalliapseudes obtusifrons appears to resemble most closely $K$. multiarticulus but can be immediately distinguished by having an antennule with an inner flagellum of 4 articles ( 7 articles in $K$. multiarticulus). It can further be distinguished by: (1) the carapace broader than long with a single pair of mid-lateral setae (carapace as long as broad with 3 pairs of mid-lateral setae in K. multiarticulus), (2) the first article of the antennule peduncle is more robust (about 2.6 times longer than wide), (3) the ventral spines of the propodus of pereopod I distinctly longer, (4) the propodus of pereopod VI with 6 long spines and 30 short comb-like spines (6 long spines and about 13 short spiniform setae in $K$. multiarticulus), (5) the dactylus of pereopod VI with 2 distal setae and 2 short spiniform 
setae on proximal half ( 1 distal seta present in $K$. multiarticulus), (6) and the exopodite of the uropod composed of 3 articles ( 2 articles in $K$. multiarticulus). The brush-like sensory organ representing the dactylus of pereopods IV and V is similar to that found in $K$. multiarticulus but distinct from the dactyli of $K$. langi and $K$. struthi. The peduncle of the antenna has only 1 short article distal to the squama in K. obtusifrons and $K$. langi, and 2 short articles in K. struthi. Kalliapseudes obtusifrons has a distinctively long terminal spiniform seta on the mandibular palp. Unfortunately this character was not described or figured for K. multiarticulus and K. struthi. A key for the separation of the four species known from Australian waters is presented below.

\section{Key to the Australian species of the genus Kalliapseudes}

1. Pereonites 2-3 with anterolateral spiniform projection; exopodite of cheliped and pereopod I with 4 plumose setae. K. langi Guțu, 2006

- Pereonites 2-3 without anterolateral spiniform projection; exopodite of cheliped and pereopod I with 2 plumose setae...

2. Dactylus of pereopods IV and V not represented by a brush-like sensory organ K. struthi Bamber, 2005

- Dactylus of pereopods IV and V represented by a brush-like sensory organ .3

3. Uropod exopodite having 3 articles; dactylus of pereopod VI with 2 distal setae and 2 short spiniform setae on proximal half. K. obtusifrons (Haswell, 1882)

- Uropod exopodite having 2 articles; dactylus of pereopod VI with 1 distal seta K. multiarticulus Guțu, 2006

\section{Acknowledgements}

We wish to thank Roger Springthorpe and Stephen Keable, Australian Museum (Natural History) for the loan of type material. We also thank the two anonymous reviewers and Kim Larsen, who provided insightful comments on the manuscript. This research was supported by a grant to R. W. Heard, G. Anderson, and J. Campbell from the National Science Foundation (DEB-0529749).

\section{Literature cited}

Băcescu, M. (1980). Contributions to the knowledge of some Kalliapseudidae (Crustacea, Tanaidacea) from the NW of the Indian Ocean. Travaux du Muséum National d'Histoire naturelle “Grigore Antipa”, 22, 359-379.

Bamber, R.N. (1998) Tanaidaceans (Crustacea, Peracarida) from the Southeast of the South China Sea. Asian Marine Biology, 15, 169-197. 
Bamber, R.N. (2005) The tanaidaceans (Arthropoda: Crustacea: Peracarida: Tanaidacea) of Esperance, Western Australia, Australia. In: Wells, F.E., Walker, D.I., \& Kendrick, G.A., (Eds.), The marine flora and fauna of Esperance, Western Australia. Western Australian Museum, Perth, pp. 613-727.

Bamber, R.N., Bird, G.J., \& Angsupanich, S. (2003) Tanaidaceans (Crustacea: Peracarida) from Thailand: new records and new species. Asian Marine Biology, 18: 35-69.

Boesch, D.F. (1973) Three new tanaids (Crustacea, Tanaidacea) from Southern Queensland. Pacific Science, 27(2), 168-188.

Drumm, D.T. (2003) Kalliapseudes (Mesokalliapseudes) macsweenyi, a new species of Kalliapseudidae (Crustacea: Tanaidacea: Apseudomorpha) from mangroves in Florida. Zootaxa, 357, $1-12$.

Guțu, M. (2006) New Apseudomorph taxa (Crustacea, Tanaidacea) of the world ocean. Bucuresti: Curtea Veche, $318 \mathrm{pp}$.

Haswell, W.A. (1882) Description of a new species of Apseudes. Proceedings of the Linnaean Society of New South Wales, 6, 748-749.

Lang, K. (1949) Contribution to the systematics and synonymies of the tanaidacea. Arkiv för Zoologi, 42A(18), 1-14.

Lang, K. (1956) Kalliapseudidae, a new family of Tanaidacea. In: Wingstrand K.G. (Ed.), Bertil Hanstroem. Zoological papers in honorus in his $65^{\text {th }}$ birthday, Nov. $20^{\text {th }}$, 1956. Zoological Institute, Lund, pp. 205-225.

Larsen, K. (2003) Proposed new standardized anatomical terminology for the Tanaidacea (Peracarida). Journal of Crustacean Biology, 23(3), 644-661.

Larwood, H.J.C. (1954) Crustacea Tanaidacea and Isopoda from the Suez Canal. Annals and Magazine of Natural History, 7, 561-577.

Leach, W.E. (1814) Crustaceology. In: Brewster, D. (Ed.), The Edinburgh Encyclopaedia. Edinburgh, pp. 383-437.

Makkaveeva, E.B. (1971) Kacestvenyi sostav I kolicestvennoie tanaidovyh rakov v Krasnom More. In: Bentos shelifa Krasnogo Moria, Izdatelstvo “Naukova Duma”, Kiev, pp. 88-108.

Menzies, R.J. (1953) The apseudid chelifera of the eastern tropical and north temperate Pacific Ocean. Bulletin of the Museum of Comparative Zoology, Harvard College, 107(9), 443-496.

Nierstrasz, H.F. (1913) Die Isopoden der Siboga-Expedition. I. Isopoda Chelifera. Siboga Expeditie, 32a, 1-56.

Richardson, H. (1912) Description of a new species of isopod belonging to the genus Apseudes from Ecuador. Proceedings of the U. S. National Museum, 42, 583-585.

Stebbing, T.R.R. (1910) No. VI. Isopoda from the Indian Ocean and British East Africa. The Percy Sladen Trust Expedition to the Indian Ocean in 1905. The Transactions of the Linnean Society of London, Series 2, Zoology, 14, 83-122 (plates V-XIV). 